\title{
ASCORBIC ACID FOLIIAR SPRAY COUNTERACTING EFFECT OF SALINITY ON GROWTH, NUTRIENTS CONCENTRATIONS, PHOTOSYNTHESIS, ANTIOXIDANT ACTIVITIES AND LIPID PEROXIDATION OF BEAN (PHASEULUS VULGARIS L.) CULTIVARS
}

\author{
${ }^{1}$ Zeinab A. Salama, ${ }^{2}$ El-Zanaty A.A. Abou El-Nour, \\ ${ }^{2}$ Mohamed M. El Fouly and ${ }^{1}$ Alaa A. Gaafar \\ ${ }^{1}$ Department of Plant Biochemistry, El Behouth Street, Dokki, Egypt \\ ${ }^{2}$ Department of Fertilization Technology, El Behouth Street, Dokki, Egypt
}

Received 2014-03-15; Revised 2014-04-10; Accepted 2014-05-16

\begin{abstract}
A water culture experiment was carried out in the Department of Fertilization Technology at National Research Centre, Cairo, Egypt, to investigate the effect of Ascorbic Acid (AsA) foliar application and salinity stress $(100 \mathrm{ppm}$ and $100 \mathrm{mmoL} \mathrm{NaCl})$ on growth, nutrients concentration and some biochemical parameters of two kidney bean (Phaseulus Vulgaris L.) cultivars. Salinity caused significant reduction in growth parameters (leaves and root dry weights) and some of biochemical parameters (nutrients concentration, photosynthesis pigment, Carbonic Anhydrase Activity (CAA), antioxidant enzyme activity Peroxidase (POD) and lipid peroxidation). The reduction effect on Paulista cultivar was higher than Nebraska cultivar at $100 \mathrm{mM} \mathrm{NaCl}$ salinity stress. Meanwhile, POD activity was increased under salt stress conditions. Lipid Peroxidation (LP) under $100 \mathrm{mmoL} \mathrm{NaCl}$ salinity was significantly increased. The two cultivars showed an increase in MDA content with $\mathrm{NaCl}$ salinity stress, but the increase in sensitive cultivars Paulista was higher than that in salt-tolerant Nebraska cultivar. Application of (AsA) not only mitigated the inhibitory effect of salt stress in both kidney bean cultivars, but also in some cases induced a stimulatory effect greater than that estimated in the control plants on growth parameters which were accompanied by marked increases in nutrients concentration and photosynthetic system (pigments and carbonic anhydrase activity). Ascorbic Acid (AsA) has been shown to be an essential antioxidant; agent may act as a scavenger of ROS for mitigating the injury on bio-membranes under salt stress. Therefore, this study suggested that (AsA) application may induce an adaptive response in kidney bean through stimulation of the antioxidant enzymes activities, photosynthesis processes and lower lipid peroxidation, in Nebraska relative to Paulista may contribute to salt tolerance mechanism in Nebraska.
\end{abstract}

Keywords: Salinity Strss, Antioxidants, Ascorbic Acid, Kidney Bean

\section{INTRODUCTION}

Salinity is one of the most important abiotic stresses which affect many aspects of plants metabolism and reduce growth and crop production (Zhu, 2002). When plants are subjected to environmental stresses, Reactive Corresponding Author: Zeinab A. Salama, Department of Plant Biochemistry, National Research Centre, El Behouth Street, Dokki, Egypt
Oxygen Species (ROS) are generated in response to stress condition (Dat et al., 2000). Salinity causes numerous physiological and biochemical changes in plants like reduced leaf size, stem extension, root proliferation, reduced water use efficiency (Farooq et al., 2009) Alteration in metabolic activities (El-Fouly and Salama, 1999), inhibition 
of enzymatic activities (Frova et al., 1999) ionic imbalance and disturbances in solute accumulation (El-Fouly et al., 2010) or a combination of all these factors. Excess of ROS causes phytotoxic reactions such as lipid peroxidation, protein degradation and DNA mutation (Wang et al., 2003).

Ascorbic acid is a natural product of plants functions play a key role as an antioxidant and an enzyme and apparently plays a role in ameliorating cofactor. It participates in a variety of processes. Ascorbic acid is associated with chloroplasts the oxidative stress of photosynthesis. In addition, AsA has a number of other roles in cell division and protein modification. One approach for inducing oxidative stress tolerance would to acts as a primary substrate in the cyclic pathway of enzymatic detoxification of hydrogen peroxide (Beltaji, 2008). Ascorbic acid application was also alleviated the destructive effects of salinity on osmotic potential, shoot and root dry mass, $\mathrm{K}^{+} / \mathrm{Na}^{+}$ratio and contents of photosynthetic pigments in wheat seedlings under salinity stress was completely affected by exogenous ascorbic acid (Kaydan et al., 2007). There were various attempts to improve the salinity tolerance of a variety of crops by traditional breeding programs. Little information on how ascorbic acid regulates physiological/biochemical processes in kidney bean plants subjected to salt stress. Therefore, this study was to evaluate the counteracting effects of ascorbic acid foliar spray on growth, nutrients concentrations, photosynthesis, antioxidants enzymes and lipid peroxidation were evaluated for two cultivars of kidney bean (Phaseulus vulgaris L.) grown hydroponically under salt stress conditions.

\section{MATERIALS AND METHODS}

\subsection{Plant Materials and Growth Conditions}

A Water culture experiment was carried out at Fertilization Technology Department, National Research Centre, Cairo, Egypt. Seeds of two cultivars of Kidney Bean Phaseulus Vulgaris L. Paulista and Nebraska were obtained from Agricultural Research Institute. The seeds were washed and soaked for several hours in aerated tap water. The germination was carried out in plastic dishes at $28^{\circ} \mathrm{C}$ in dark. Three days-old seedlings were put to grow in plastic pots filled with one-tenth concentration of Hoagland and Arnon (solution $(\mathrm{pH} \mathrm{6.0)}$ containing 5 $\mathrm{mMCa}\left(\mathrm{NO}_{3}\right)_{2} .4 \mathrm{H}_{2} \mathrm{O}, 5 \mathrm{mM} \mathrm{KNO}, 1 \mathrm{mM} \mathrm{K \textrm {K } _ { 2 }} \mathrm{PO}_{4}, 2$ $\mathrm{mM} \mathrm{MgSO}{ }_{4} .7 \mathrm{H}_{2} \mathrm{O}$ and micronutrients in $\mu \mathrm{M}: \mathrm{H}_{3} \mathrm{BO}_{3}-0$, $\mathrm{MnCl}_{2}-0.5, \mathrm{ZnSO}_{4}-0.5, \mathrm{CuSO}_{4}-0.2, \mathrm{Na}_{2} \mathrm{MoO}_{4}-0.1, \mathrm{Fe}$ (III)-HEDTA -20). The seedlings were grown in an environmental growth chamber under $16 \mathrm{~h}$ light at 120 $\mu \mathrm{moL} \mathrm{m}-2 \mathrm{sec}-1$ provided by fluorescent tubes, $8 \mathrm{~h}$ night, $60 \%$ Relative Humidity $(\mathrm{RH})$ at $25^{\circ} \mathrm{C}$ day $/ 20^{\circ} \mathrm{C}$ night temperature. Two days later the plants were divided into four variants (plus and minus $\mathrm{NaCl}$ ) with and without spraying ascorbic acid (0.00-100 ppm) (50$100 \mathrm{~mL}$ ) were applied for each pot. It was used to correct the nutrient imbalance caused by salt stress conditions. At 21 days old. Samples were taken for plant growth measurements and determine of nutrient contents according to (Chapman and Pratt, 1978).

\subsection{Chemicals}

All Chemicals were of the Highest Commercial Grade and Obtained from Sinopharm Chemical Reagent Co. Ltd. (Shanghai, China).

\subsection{Nutrients concentration}

Total elements were analyzed after digestion of plant samples with mixture of concentrated $\mathrm{HSO}_{4}$ and perchloric acids. The total macro and micronutrient concentrations: $\mathrm{K}, \mathrm{Ca}$ and $\mathrm{Mg}, \mathrm{Fe}, \mathrm{Mn}$ and $\mathrm{Zn}$ were analyzed in plant digests using Flame photometer and atomic-absorption spectrophotometry. All macronutrients were expressed in g/100 gdry matter and micronutrient concentrations were expressed in $\mathrm{mg} / \mathrm{kg}$ DW according to (Chapman and Pratt, 1978).

\subsection{Chlorophyll Measurement}

Samples (100 mg leaves) were homogenized in chilled $80 \%(\mathrm{v} / \mathrm{v})$ acetone and centrifuged at $10000 \mathrm{~g}$ for $10 \mathrm{~min}$ at $4{ }^{\circ} \mathrm{C}$. Absorbance of the acetone extracts was measured at 663 and 645 according to (Lichtenthaler, 1987).

\subsection{Enzyme Assays}

\subsubsection{Preparation of Enzyme Extracts}

About $5.0 \mathrm{~g}$ were crushed into fine powder using liquid nitrogen. Soluble protein was extracted by homogenizing the powder in $10 \mathrm{~mL}$ of $50 \mathrm{mM}$ phosphate buffer ( $\mathrm{pH} 7.8$ ) containing 1mM EDTA and 1\% PVP, with the addition of $1 \mathrm{mM}$ ascorbate in the case of POD assay at $4^{\circ} \mathrm{C}$. The homogenate was centrifuged at $15,000 \times \mathrm{g}$ for $20 \mathrm{~min}$ and the supernatant was used for the following enzyme activity assay.

\subsubsection{Peroxidase Activity (EC1.11.1.7) Assay}

Peroxidase activity was assayed by monitoring the increase in absorbance at $430 \mathrm{~nm}$ due to the oxidation of pyrogallol (Amako et al., 1994) The reaction mixture consisted of $50 \mathrm{mM}$ potassium phosphate buffer ( $\mathrm{pH} 7.0$ ), $20 \mathrm{Mm}$ pyrogallol, $5 \mathrm{mM} \mathrm{H}_{2} \mathrm{O}_{2}$ and $20 \mu \mathrm{L}$ of enzyme extract. One unit of enzyme was the amount necessary to 
decompose $1 \mu \mathrm{moL}$ of substrate per minute at $25^{\circ} \mathrm{C}$. Peroxidase activity was expressed as EU/gfw/ $\mathrm{min}^{-1}$.

\subsubsection{Carbonic Anhydrase Activity Assay (EC 4.2.1.1)}

Leaves tissue (100 mg FW) were placed into liquid nitrogen and then homogenized with a buffered solution ( $\mathrm{pH}$ 8.3) that contained $50 \mathrm{~mm}$ Veronal$\mathrm{H}_{2} \mathrm{SO}_{4}$ and $0.2 \%$ (w/v) PVP under ice cold-conditions. The homogenate was centrifuged at $12,000 \mathrm{~g}$ for $2 \mathrm{~min}$ and the supernatant was used for the determination of CA activity according to (Ohki, 1978).

\subsubsection{Determination of Lipid Peroxidation (L.P)}

Lipid peroxidation was measured as the amount of MDA determined by the Thiobarbituric Acid (TBA) reaction (Heath and Packer, 1968). Frozen samples were homogenized with a pre-chilled mortar and pestle with two volumes of ice-cold $0.1 \%$ (w/v) TCA and centrifuged for $15 \mathrm{~min}$ at $15000 \mathrm{~g}$. Assay mixture containing $1 \mathrm{~mL}$ of the supernatant and $2 \mathrm{~mL}$ of $0.5 \%(\mathrm{w} / \mathrm{v}) \mathrm{TBA}$ in $20 \%$ (w/v) TCA was heated at $95^{\circ} \ddot{e}$ for $30 \mathrm{~min}$ and then rapidly cooled in an ice bath. After centrifugation (10000 $\mathrm{g}$ for 10 $\min$ at $4^{\circ} \mathrm{C}$ ), the supernatant absorbance was read at 532 $\mathrm{nm}$ and the values corresponding to nonspecific absorption $(600 \mathrm{~nm})$ were subtracted. Lipid peroxidation products were measured as the content of TBA-reactive substances. The MDA content was calculated according to the molar extension coefficient of $155 /\left(\mathrm{mM} \mathrm{cm}^{-1}\right)$.

\subsection{Statistical Analysis}

Data were statistically analyzed using Costat statistical package according to (Anonymous, 2000).

\section{RESULTS}

\subsection{Effect of (AsA) Foliar Spray on the Plant Growth of Kidney Bean Cultivars Grown In Salinized Media}

Data presented in (Fig. 1) indicate the effect of (AsA) foliar spray on growth (leaves and roots) dry matter per plant) of Kidney Bean cultivars grown in salinized media. $\mathrm{NaCl}$ Salinity had a negative effect on shoot and root dry weights for Nebraska. At $100 \mathrm{mM} \mathrm{NaCl}$ treatment, reduction in dry weight was more in both saltsensitive and a salt tolerant kidney bean plant when compared with control (Fig. 1). Ascorbic acid application alleviated the $\mathrm{NaCl}$ toxicity and minimized the reduction in dry weights caused by $\mathrm{NaCl}$. In general, effects of ascorbic acid in mitigating the adverse effects of salt stress have been described to activation of some of the enzymatic reactions. It is evident that ascorbic acid plays a key role in the regulation of a number of metabolic processes in plants exposed to salt stress.

Ascorbic acid application alleviated the $\mathrm{NaCl}$ toxicity and minimized the reduction in dry weights caused by $\mathrm{NaCl}$. In general, effects of ascorbic acid in mitigating the adverse effects of salt stress have been described to activation of some of the enzymatic reactions. It is evident that ascorbic acid plays a key role in the regulation of a number of metabolic processes in plants exposed to salt stress.

\subsection{Effect of (AsA) Foliar Spray on Nutrients Concentration of Kidney Bean Cultivars Grown in Salinized Media}

Concerning nutrients concentration in leaves of bean cultivars, high salt concentration in the growth root medium was found to limit the uptake of all determined nutrients with different degrees. Potassium (K, $\mathrm{Ca}$ and $\mathrm{Mg}$ ) tended to decrease with $\mathrm{NaCl}$ level increase. Salinity induced $\mathrm{K}^{+}$deficiency. Also, reduced $\mathrm{Ca}$ and $\mathrm{Mg}$ contents in leaves of both cultivars (Fig. 2). Reduction of iron concentration was higher in the aerial parts compared to control Unexpected results for Mn concentration it was greatly increased in both cultivars with treatment 100 mmol $\mathrm{NaCl}$, while $\mathrm{Zn}$ concentration in the arial parts of both cultivars were slightly decreased compared with control plants. Ascorbic acid spray improved the performance of root growth and prevented the nutritional disorders and consequently caused increases of macronutrients and micronutrients uptake (Fig. 2).

\subsection{Effect of Ascorbic Acid (AsA) Foliar Spray on Photosynthetic Pigments Content in Leaves of Kidney Bean Cultivars Grown In Saline Media}

The effect of salinity in presence or absence of (AsA) on photosynthesis pigments is presented in (Table $\mathbf{1}$ ). Imposition of salt stress caused a significant reduction in chlorophyll $\mathrm{a}, \mathrm{b}$ and total chlorophyll $(\mathrm{a}+\mathrm{b})$ of the seedlings of both cultivars. Application of 100 ppm ascorbic acid as a foliar spray enhanced chlorophyll $a$, chlorophyll $b$ and $\mathrm{T}$ Chl. content in both bean cultivars under saline conditions (Table 1). The reduction in photosynthetic pigments was significantly in Nepraska compared to paulista cultivar. Application of Vit C. did not only alleviate the inhibitory effect of salinity stress on the biosynthesis photosynthetic pigments, but also induced a significant stimulatory effect greater than observed in the control treatment. 
Zeinab A. Salama et al. / American Journal of Agricultural and Biological Sciences 9 (3): 384-393, 2014

Table 1. Effect of ascorbic acid $100 \mathrm{ppm}$ in presence or absence of $100 \mathrm{NaCl}$ on Chl.a, Chl.b,T.Chl.(a+b), CAA, POD and L.P grown hydroponically for three weeks

\begin{tabular}{|c|c|c|c|c|c|c|}
\hline Treatments & $\begin{array}{l}\text { Chl.a } \\
\mu \mathrm{g} / \mathrm{fw}\end{array}$ & $\begin{array}{l}\text { Chl.b } \\
\mu \mathrm{g} / \mathrm{fw}\end{array}$ & $\begin{array}{l}\text { Chl }(a+b) \\
\mu g / f w\end{array}$ & $\begin{array}{l}\text { CA } \\
\text { EU/gfw }\end{array}$ & $\begin{array}{l}\text { POD } \\
\mathrm{EU} / \mathrm{gfw} / \mathrm{min}^{-1}\end{array}$ & $\begin{array}{l}\text { L.P } \\
\mu \mathrm{mol} / \mathrm{fw}\end{array}$ \\
\hline \multicolumn{7}{|l|}{ Paulista } \\
\hline Control & $16.65^{\mathrm{c}}$ & $6.21^{\mathrm{c}}$ & $22.86^{\mathrm{c}}$ & $214^{\mathrm{c}}$ & $240^{\mathrm{b}}$ & $2.50^{\mathrm{a}}$ \\
\hline Control+Vit.C & $17.17^{\mathrm{d}}$ & $6.35^{\mathrm{c}}$ & $23.52^{\mathrm{c}}$ & $315^{\mathrm{d}}$ & $334^{c}$ & $2.70^{\mathrm{b}}$ \\
\hline $100 \mathrm{mmolNaCl}$ & $11.48^{\mathrm{a}}$ & $4.83^{\mathrm{a}}$ & $16.31^{\mathrm{a}}$ & $164^{\mathrm{a}}$ & $421^{\mathrm{d}}$ & $4.16^{\mathrm{d}}$ \\
\hline $\mathrm{NaCl}+\mathrm{Vit} . \mathrm{C}$ & $13.33^{\mathrm{b}}$ & $5.34^{\mathrm{b}}$ & $18.67^{\mathrm{b}}$ & $175^{\mathrm{b}}$ & $143^{\mathrm{a}}$ & $3.12^{\mathrm{c}}$ \\
\hline LSD at 0.05 & 0.07 & 0.42 & 0.87 & 6.26 & 36.23 & 0.29 \\
\hline \multicolumn{7}{|l|}{ Nebraska } \\
\hline Control & $18.53^{\mathrm{b}}$ & $7.50^{\mathrm{c}}$ & $26.03^{\mathrm{a}}$ & $415^{\mathrm{c}}$ & $592^{\mathrm{ab}}$ & $3.60^{\mathrm{a}}$ \\
\hline Control+Vit.C & $21.29^{\mathrm{c}}$ & $8.06^{\mathrm{d}}$ & $29.35^{b}$ & $401^{\mathrm{b}}$ & $948^{\mathrm{b}}$ & $2.80^{\mathrm{b}}$ \\
\hline $100 \mathrm{mmolNaCl}$ & $9.77^{\mathrm{b}}$ & $4.02^{\mathrm{a}}$ & $13.79^{c}$ & $328^{\mathrm{a}}$ & $950^{\mathrm{ab}}$ & $3.60^{\mathrm{b}}$ \\
\hline $\mathrm{NaCl}+\mathrm{Vit} . \mathrm{C}$ & $10.37^{\mathrm{a}}$ & $4.42^{\mathrm{b}}$ & $14.79^{\mathrm{d}}$ & $401^{\mathrm{b}}$ & $336^{\mathrm{a}}$ & $3.80^{\mathrm{b}}$ \\
\hline LSD at 0.05 & 0.40 & 0.28 & 0.53 & 10.51 & 303.32 & 0.33 \\
\hline
\end{tabular}

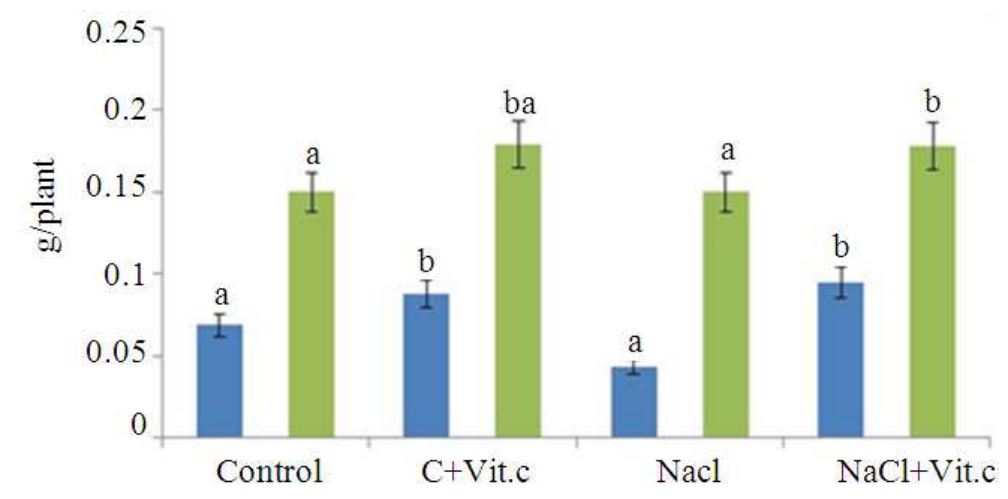

-Paulista $\quad$ Nebraska

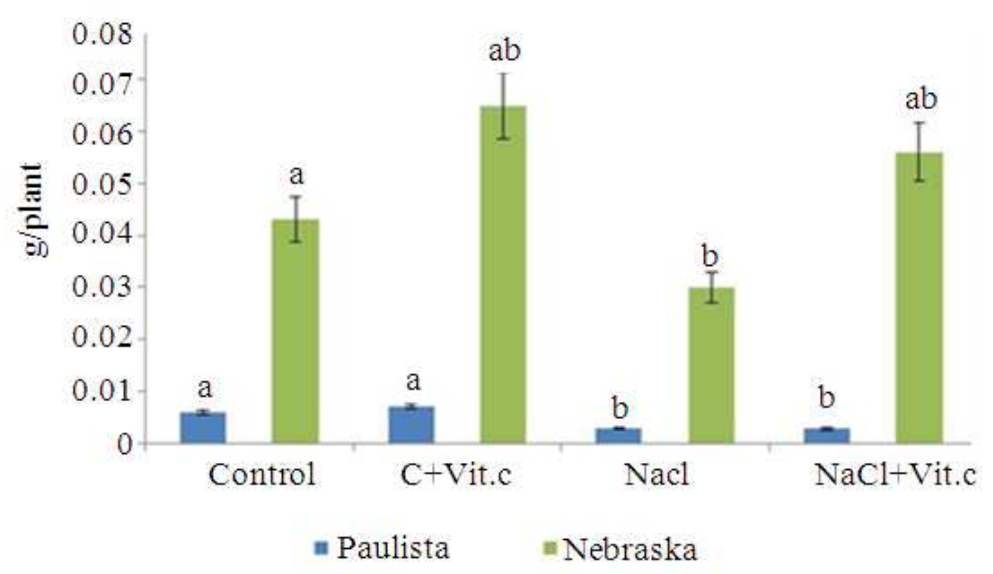

Fig. 1. Effect of ascorbic acid $100 \mathrm{ppm}$ foliar spray in presence or absence of $100 \mathrm{NaCl}$ on leaves and root dry weight (g/plant) of two cultivars of kidney bean grown hydroponically for three weeks 
Zeinab A. Salama et al. / American Journal of Agricultural and Biological Sciences 9 (3): 384-393, 2014
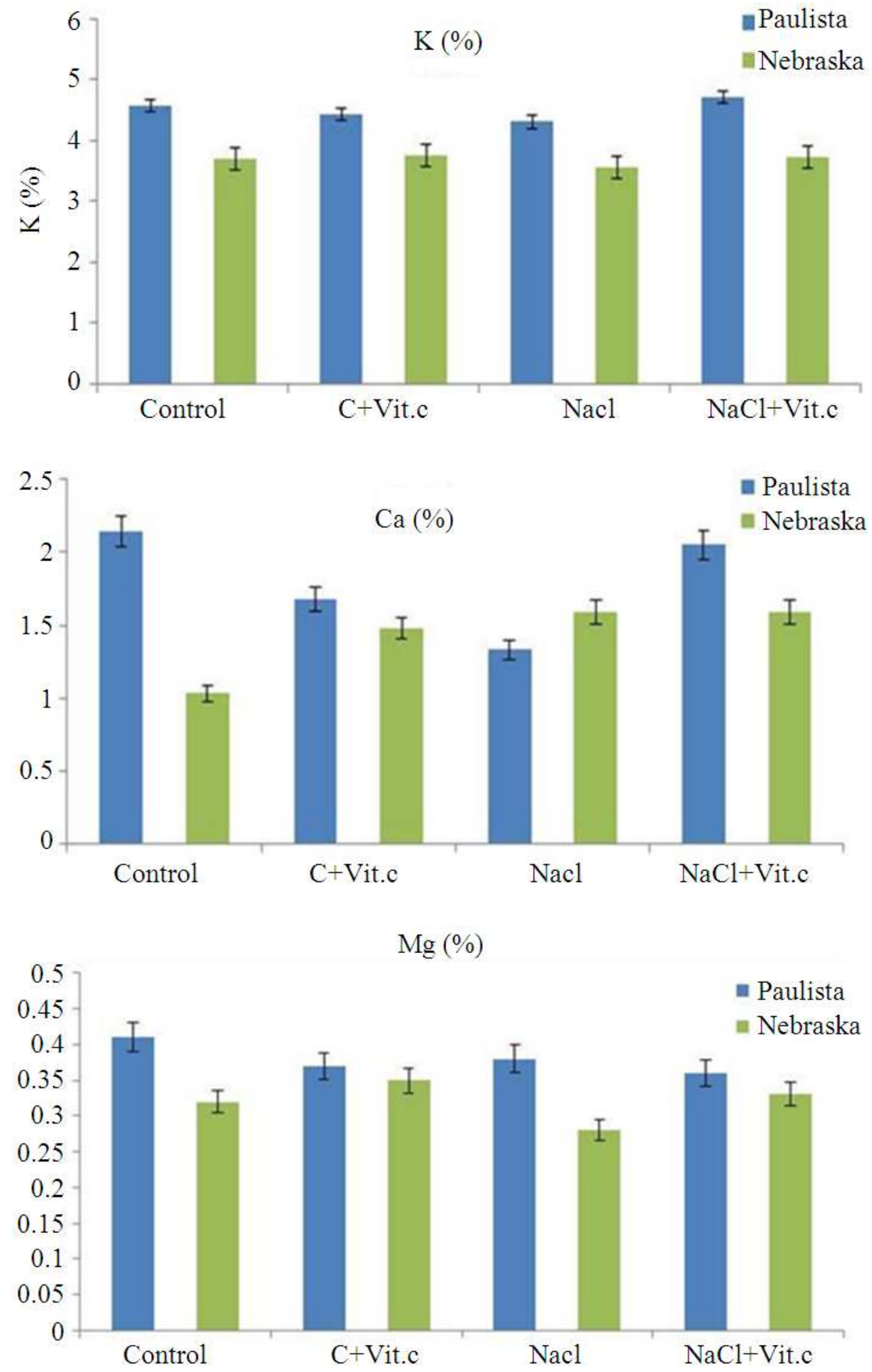

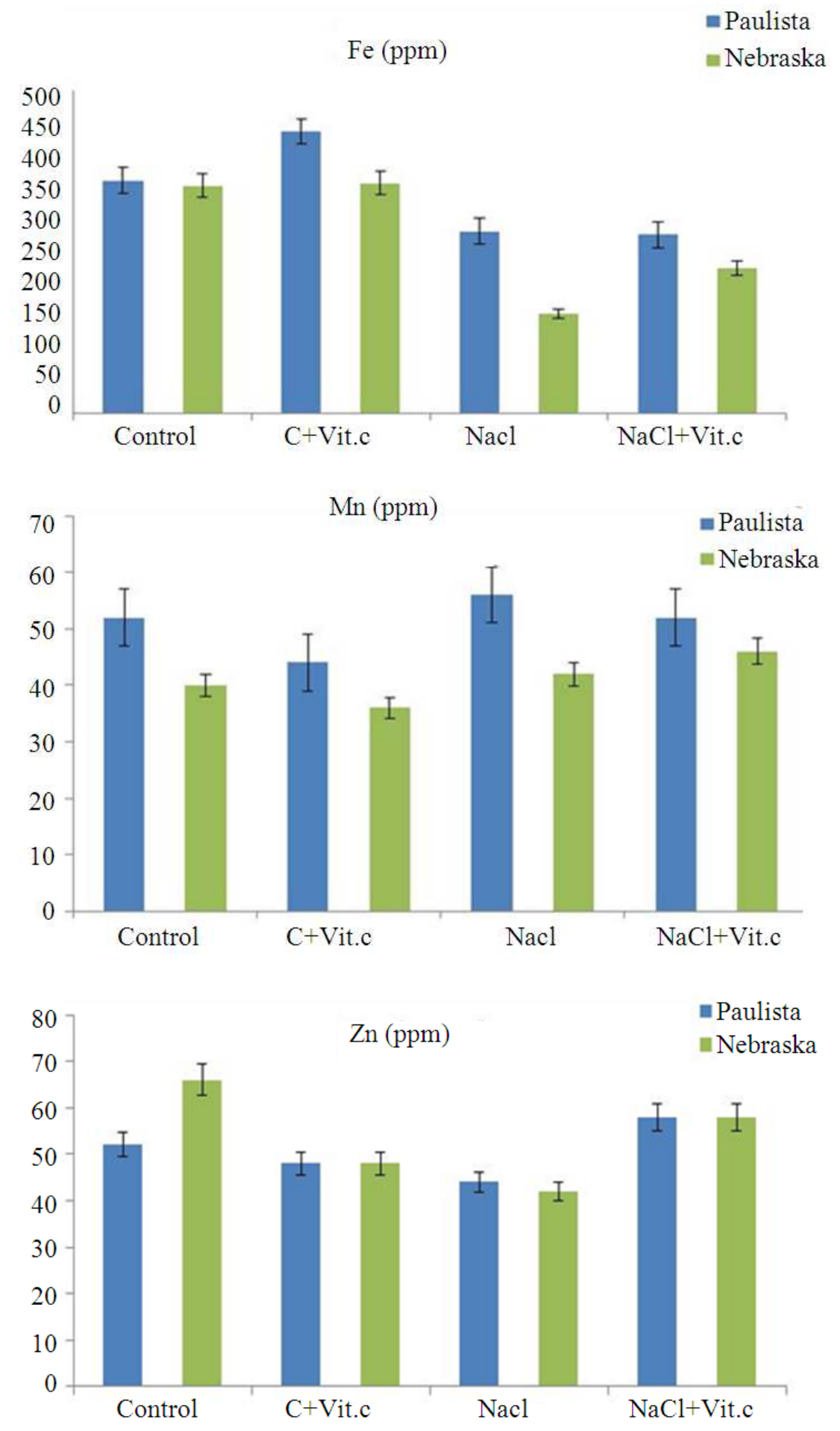

Fig. 2. Effect of ascorbic acid $100 \mathrm{ppm}$ in presence or absence of $100 \mathrm{NaCl}$ on $\mathrm{K}, \mathrm{Ca}, \mathrm{Mg}, \mathrm{Fe}, \mathrm{Mn}$ and $\mathrm{Zn}$ concentration of two cultivars kidney bean grown hydroponically for three weeks 


\subsection{Effect of Ascorbic Acid (AsA) Foliar Spray on Carbonic Anhydrase Activity (CAA) in Leaves of Kidney Bean Grown in Saline Media}

The effect of $\mathrm{NaCl}$ on CAA for two cultivars of bean was presented in (Table 1). The activity of CA was significantly decreased by the $\mathrm{NaCl}$ treatment (Table 1). The photosynthetic carbon assimilation process in bean cultivars was found to be significantly depressed by 100 mmoL NaCl. The inhibition of CAA after adding 100 mmoL $\mathrm{NaCl}$ was (23.4 and 21\%) for Paulista and Nebraska with respect to control. There was an unexpected decline on CAA activity when $100 \mathrm{ppm}$ (AsA) was applied for non saline conditions. Ascorbic acid treatment improved the activities of CA in Paulista plants that were subjected to salinity stress. While no change in the activities of $\mathrm{CA}$ in Nebraska plants receiving both $\mathrm{NaCl}(100 \mathrm{mM})$ and $\mathrm{AsA}$.

\subsection{Effect of Ascorbic Acid (AsA) Foliar Spray on Antioxidant Enzyme Activity (POD) in Leaves of Kidney Bean Cultivars Grown in Saline Media}

A considerable increase in the peroxidase activity in leaves of kidney bean cultivars grown with $\mathrm{NaCl}$ $100 \mathrm{mmoL}$ are shown in (Table 1). The highest enzyme POD activity of plants maintained at 100 mmoL NaCl level was 421 and $950 \Delta \mathrm{A} / \mathrm{gfw}$ min-1 for Paulisita and Nebraska respectively. The POD activity decreased to 143 and $336 \Delta \mathrm{A} / \mathrm{gfw}$ min-1 for Paulista and Nebraska after (AsA) application. POD was higher in salt-tolerant Nebraska than in salt-sensitive Paulista at $100 \mathrm{mmoL} \mathrm{NaCl}$ treatment.

\subsection{Effect of (AsA) Foliar Spray on Lipid Peroxidation of Kidney Bean Cultivars Grown in Salinized Media}

To evaluate the $\mathrm{NaCl}$-induced oxidative damage to the cell membranes, the content of Thiobarbituric Acid Reactive Substances (TBARS) was determined. Lipid peroxidation in leaves of both kidney bean cultivars, measured as MDA content, is given in (Table 1). $\mathrm{NaCl}$ treatments led to an increase in the levels of MDA in both cultivars. Data presented in (Table 1) showed that (LP) gave its higher value (4.16 and $3.60 \mu \mathrm{mol.gfw}^{-1}$ ) when Paulista and Nebraska grown with $\mathrm{NaCl} 100 \mathrm{mmol}$ compared to control (2.5 and 3.6 umol.gfw $^{-1}$. Accumulation of MDA in Paulista, however, was higher than in Nebraska, indicating a higher degree of lipid peroxidation due to salt stress. Nebraska showing better growth, had less MDA and under salt stress had less MDA than Paulista, exhibited less active lipid peroxidation, indicating that Nebraska was the salttolerant cultivar. This indicates that salt-tolerant cultivar induced capability of plant protection against oxidative damage caused by salt treatment.

\section{DISCUSSION}

The present study explore the countracting effect of (AsA) on two cultivars of kidney bean paulista and nebraska under salinity stress conditions. Under saline conditions results of our investigation showed that salt stress reduced plant growth for both cultivars.

It has been reported that the typical symptom of salinity injury to the plant is growth retardation due to the inhibition of cell elongation (Fariduddin et al., 2003). In this study, when subjected to $100 \mathrm{mmoL} \mathrm{NaCl}$, both cultivars Paulista and Nebraska. Showed a reduction in plant growth. The response of two kidney bean cultivars to salt stress was found to be different. Nebraska showed better growth than Paulista under salt stress conditions.

Reduction of plant growth by salinity has been reported in several grain legumes, including Phaseolus vulgaris, the decrease of leaves and roots dry weight may be attributed to $\mathrm{NaCl}$ altering the water potential, increase ion toxicity or causing ion imbalance (Al-Ansari, 2003; Morant-Manceau et al., 2004). Such depressive effect of salinity in peas growth may be also, attributed to the adverse effect on enzymatic processes through some interactions of salts and some organic substances of the cell (Oertil, 1996). In general, effects of ascorbic acid in mitigating the adverse effects of salt stress have been described to activation of some of the enzymatic reactions. It is evident that ascorbic acid plays a key role in the regulation of a number of metabolic processes in plants exposed to salt stress.

High salt concentration in the growth root medium was found to limit the uptake of all determined nutrients with different degrees. Under salt stress Salinity induced $\mathrm{K}^{+}$deficiency which has been implicated in growth and yield reduction of various crops, spinach (Chow et al., 1990) and maize (Botella et al., 1997). The increment of $\mathrm{Ca}$ concentration in the leaves of Nebraska cultivar may be due to that most of $\mathrm{Ca}$ migrates to the shoot as an osmoregulation to resist salt determined effects on shoot cells. Reduction of iron concentration was higher in the aerial parts compared to control which suggest that $\mathrm{Fe}$ accumulates in the roots because of lack of the processes energize translocation and a $\mathrm{pH}$ effect (Carvajal et al., 1999). These findings are also agree with results obtained by (Achakzai, 2008) in sorghum and maize seedlings subjected to various levels of water stress conditions, as well as in uptake and accumulation of 
macronutrients by wheat as reported by (Achakzai, 2008). Ascorbic acid application (100 ppm) increased the concentration of $\mathrm{K}, \mathrm{Ca}, \mathrm{Mg}, \mathrm{Fe}, \mathrm{Mn}$ and $\mathrm{Zn}$. Ascorbic acid spray improved the performance of root growth and prevented the nutritional disorders and consequently caused increases the uptake of nutrients (El-Fouly and Salama, 1999; El-Fouly et al., 2002; 2010). It has been found that ascorbic acid strongly inhibited $\mathrm{Na}^{+}$and $\mathrm{Cl}^{-}$accumulation of salt stressed maize plants, but stimulated $\mathrm{N}, \mathrm{Mg}, \mathrm{Fe}, \mathrm{Mn}$ and $\mathrm{Cu}$ concentrations. These results suggest that ascorbic acid could be used as a potential growth regulator to improve plant salinity stress resistance (Gunes et al., 2007).

The decrease of photosynthesis pigments under salt stress due to stomata closure, inhibition of chlorophyll synthesis, a decrease of carboxylase due to high chlorophylase activity (Batanouny et al., 1991). Also, (Agastian et al., 2000) reported that the changes in leaf chlorophyll content may have been due to reduced biosynthesis or increased degradation of chlorophyll under saline conditions. Furthermore, (Mittler, 2002) suggested that in salt stressed plants, breakdown of ultrastructure of chloroplasts including plastid envelop, thylakoids and photosynthetic apparatus may result due to direct $\mathrm{Na}^{+}$toxicity or salt-induced oxidative damage. Adverse effect of salt stress on chlorophyll ' $a$ ' was counteracted by (AsA) application. Smirnoff (1993) stated that ascorbate has a central role in photosynthesis in chloroplast and protected photosynthetic apparatus from salt induced oxidative stress. Ascorbic acid treatment also increased the level of chlorophyll in the present investigation. Which is well supported by the earlier observations in wheat and/or mung bean seedlings under stress free conditions (Moharekar et al., 2003; Hayat et al., 2005) as well as under water stress (Singh and Usha, 2003).

Salt stress is reported to damage the photosynthetic machinery at multiple levels, such as pigments, stomatal functioning and gaseous exchange, structure and function of thylakoid membrane, electron transport and the sensitivity of CAA to chloride ions (Sudhir and Murthy, 2004). Excess salt concentration cause the closure of stomata, by decreasing the partial $\mathrm{CO}_{2}$ pressure (Bethkey and Drew, 1992) as well as internal $\mathrm{CO}_{2}$ concentration and consequently the activity of carbonic anhydrase (Table 1). There was an unexpected decline on CAA activity when 100 ppm (AsA) was applied none saline conditions because its activity is to large extent regulated by the $\mathrm{CO}_{2}$ concentration (Tiwari et al., 2005). Therefore, the level of CAA in treated plants with (AsA) was lower than those which did not receive (AsA) treatment due to increased stomatal conductance as well as the internal $\mathrm{CO}_{2}$ concentration in stress-free plants (Fariduddin et al., 2003). Ascorbic acid treatment also improved the activities of $\mathrm{CA}$ in the plants that were subjected to salinity stress. The activities of enzyme CA in the plants receiving both $\mathrm{NaCl}(100 \mathrm{mM})$ and AsA were 6.7 and $22.30 \%$ higher than those receiving $\mathrm{NaCl}$ $(100 \mathrm{mM})$ alone. Ascobicacid (AsA) plays a key role in the activation of rubisco and PEP carboxylase and CA under stress as documented by explain the (AsA) mediated elevation in the activity of CAA is that it corrects the stress mediated damage to the plasma membrane, as evident from an increase in the membrane stability (Khan et al., 2003).

A considerable increase in the peroxidase activity POD of paulista and Nebraska cultivars at $100 \mathrm{mmoL}$ $\mathrm{NaCl}$ treatment. Over expression of the POD gene in plant has been reported to improve protection against oxidative stress (Wang et al., 2003). These results are consistent with observations of many researchers who reported that POD activity plays a central protective roleduring salts tress (Neto et al., 2006). These enzymes were also reported to be important insalt tolerance in mulberry (Sudhakar et al., 2001) and maize genotypes (Neto et al., 2006).

$\mathrm{NaCl}$ treatments led to a significant increase in the content of MDA in both kidney bean cultivars. Nebraska cultivar showing better growth under salt stress had less MDA than Paulista indicating that salt-tolerant Nebraska exhibited less active lipid peroxidation under $100 \mathrm{mmoL}$ $\mathrm{NaCl}$ salinity treatment than the salt-sensitive Paulista. This indicates that salt-tolerant cultivar induced capability of plant protection against oxidative damage caused by salt treatment. $\mathrm{NaCl}$ application was stimulatory for MDA acumilation which almost higher in Paulista. Lipid Peroxidation (LP) is associated with damages provoked by a variety of environmental stresses. Poly-Unsaturated Fatty Acids (PUFA) are the main membrane lipid components susceptible to peroxidation and degradation (Elkahoui et al., 2005). The increase in LP, as caused by $\mathrm{NaCl}$ stress in the present study, can be correlated to ion accumulation and AOS production under salt stress (Hernandez et al., 2000). The LP level indicates the extent of salt tolerance in the given cultivars (Bor et al., 2003; Neto et al., 2006).

\section{CONCLUSION}

Our results indicate that, even if oxidative stress is induced in kidney bean plants grown under $\mathrm{NaCl}$ salt stress reduced all growth parameters, nutrients uptake, 
photosynthesis mechanism, antioxidant system which involved as one of the factors responsible for salt tolerance in Nebraska cultivar, application of foliar treatment with ascorbic acid could stimulate all the above mentioned parameters under normal and salt salinity stress. The two cultivars used have different mechanism to adapt to salt stress. Based on the responses and the ability of the kidney bean cultivars to cope with salinity stress, cultivar Nebraska could be recorded as more salt tolerance than Paulista.

\section{ACKNOWLEDGMENT}

This study was done in the frame of the cooperation between National Research Centre (NRC) and Popov Institute for Plant Physiology Sofia-Bulgaria (Egyptian Academy of Science and Technology-Bulgarian Academy of Science). It was supported by the Egypto-German Project "Micronutrient and other Plant Nutrition Problems" implemented by the National Research Centre (NRC) The project was supported by the Egyptian Academy of Science and Technology and the German Fedral Ministry of Technical Cooperation (BMZ) through the German Agency For Technical Cooperation (GTZ).

\section{REFERENCES}

Achakzai, A.K.K., 2008. Effect of water stress on cations accumulation by maize seedlings (Zea mays L.). J. Chem. Soc. Pak., 30: 271-275.

Agastian, P., S.J. Kingsley and M. Vivekanandan, 2000. Effect of salinity on photosynthesis and biochemical characteristics in mulberry genotypes. Photosynthetica., 38: 287-290. DOI: 10.1023/A:1007266932623

Al-Ansari, F.M., 2003. Salinity tolerance during germination in twparidland varieties of wheat (Triticumaestivum L.). Seed Sci. Technol., 31: 597-603.

Amako, K., G.X. Chen and K. Asada, 1994. Separate assays specific for ascorbate peroxidase and guaiacol peroxidase and for the chloroplastic and cytosolic of ascorbate peroxidise in plants. Plant Cell Physiol., 35: 497-504.

Anonymous, A., 2000. Indian Agriculture in Brief. 1st Edn., Directorate of Economics and Statistics, New Delhi.

Batanouny, K.H., M.M. Hussein and M.S.A. AboElkheir, 1991. Response of Zea mays to temporal variation of irrigation and salinity under farm conditions in the Nile delta.
Beltaji, M.S., 2008. Exogenous ascorbic acid (vitamin C) induced anabolic changes for salt tolerance in chick pea (Cicer arietinum L.) plants. Afr. J. Plant Sci., 2: 118-123.

Bethkey, P.C. and M.C. Drew, 1992. Stomatal and nonstomatal components to inhibition of photosynthesis in leaves of Capsicum annuum during progressive exposure to nacl salinity. Plant Physiol., 99: 219-226. PMID: 16668853

Bor, M., F. Ozdemir and I. Türkan, 2003. The effect of salt stress on lipid peroxidation and antioxidants in leaves of sugar beet Beta vulgaris L. and wild beet Beta maritima L. Plant Sci., 164: 77-84. DOI: 10.1016/S0168-9452(02)00338-2

Botella, M.A., V. Martinez and J.C. Pardines, 1997. Salinity induced potassium deficiency in maize plants. J. Plant Physiol., 150: 200-205. DOI: 10.1016/S0176-1617(97)80203-9

Carvajal, M., V. Martineze and A. Cerda, 1999. Influence of magnesium and salinity on tomato plants grown in hydroponic culture. J. Plant Nutr., 22: 177-190. DOI: 10.1080/01904169909365616

Chapman, H.D. and P.F. Pratt, 1978. Methods of Analysis for Soils, Plants and Waters. 1st Edn., Division Agric. Sci., Univ. California, Berkeley, U.S.A. pp: 309.

Chow, W.S., M.C. Ball and J.M. Anderson, 1990. Growth and photosynthetic responses of spinach to salinity: Implications of $\mathrm{K}^{+}$nutrition for salt tolerance. Aus. J. Plant Physiol., 17: 563-578. DOI: 10.1071/PP9900563

Dat, J., S. Vandenabeele, E. Vranova, M. van Montagu and D. Inze et al., 2000. Dual action of the active oxygen species during plant stress responses. Cell Mol. Life Sci., 57: 779-795. DOI: 10.1007/s000180050041

Neto, A.D.D.A., J.T. Prisco, J. Enéas-Filho, C.E.B. de Abreu and E. Gomes-Filho, 2006. Effect of salt stress on antioxidative enzymes and lipid peroxidation in leaves and roots of salt-tolerant and salt-sensitive maize genotypes. Environ. Exp. Botany, 56: 87-94. DOI: 10.1016/j.envexpbot.2005.01.008

El-Fouly, M.M. and Z.A. Salama, 1999. Can foliat fertilization increase plant tolerance to salinity? Dahlia Greidinger Inter. Symp. Nutrient Manage. Under Salinity Water Stress. 1: 113-125.

El-Fouly, M.M., Z.M. Mobarak and Z.A. Salama, 2002. Micronutrient foliar application control salination for horticultural productivity. Acta Hortic, 573: 377-385. 
El-Fouly, M.M., Z.M. Mobarak and Z.A. Salama, 2010. Improving tolerance of faba bean during early growth stages to salinity through micronutrients foliar spray. Not. Sci. Biol., 2: 98-102.

Elkahoui, S., J.A. Hernandez, C. Abdelly, R. Ghrir and F. Limam et al., 2005. Effects of salt on lipid peroxidation and antioxidant enzyme activities of Catharanthus roseus suspension cells. Plant Sci., 168: 607-613. DOI: 10.1016/j.plantsci.2004.09.006

Fariduddin, Q., S. Hayat and A. Ahmad, 2003. Salicylic acid influences net photosynthetic rate, carboxylation efficiency, nitrate reductase activity and seed yield in Brassica juncea. Photosynthetica, 41: 281-284. DOI: 10.1023/B:PHOT.0000011962.05991.6c

Farooq, M., A. Wahid, N. Kobayashi, D. Fujita and S.M.A. Basra et al., 2009. Plant drought stress: Effects, mechanisms and management. Agronomy Sustainable Dev., 29: 185-212. DOI: 10.1051/agro:2008021

Frova, C., P. Krajewski, N. Di-Fonzo, M. Villa and M. Sari-Gorla, 1999. Genetic analysis of drought tolerance in maize by molecular markers I. Yield components. Theoret. Applied Genet., 99: 280288. DOI: $10.1007 / \mathrm{s} 001220051233$

Gunes, A., A. Inal, M. Alpaslan, F. Eraslan and E.G. Bagci et al., 2007. Salicylic acid induced changes on some physiological parameters symptomatic for oxidative stress and mineral nutrition in maize (Zea mays L.) grown under salinity. J. Plant Physiol., 164: 728-736. DOI: 10.1016/j.jplph.2005.12.009

Hayat, S., Q. Fariduddin, B. Ali and A. Ahmad, 2005. Effect of salicylic acid on growth and enzyme activities of wheat seedlings. Acta Agron. Hung., 53: 433-437. DOI: 10.1556/AAgr.53.2005.4.9

Heath, R.L. and L. Packer, 1968. Photoperoxidation in isolated chloroplasts: I. Kinetics and stoichiometry of fatty acid peroxidation. Arch. Biochem. Biophys., 125: 189-198. DOI: 10.1016/0003-9861(68)90654-1

Hernandez, J.A., A. Jimenez, P. Mullineaux and F. Sevilla, 2000. Tolerance of pea (Pisum sativum L.) to long-term salt stress is associated with induction of antioxidant defences. Plant Cell Environ., 23: 853-862. DOI: 10.1046/j.1365-3040.2000.00602.x

Kaydan, D., M. Yagmur and N. Okut, 2007. Effects of salicylicacid on the growth and some physiological characters in salt stressed wheat (Triticum aestivum L.). Tarim Bilimleri Dergisi, 13: 114-119.

Khan, N., B. Prithviraj and D.L. Smith, 2003. Photosynthetic responses of corn and soybean to foliar application of salicylates. J. Plant Physiol., 160: 485-492. DOI: 10.1078/0176-1617-00865
Lichtenthaler, H.K., 1987. Chlorophylls and carotenoids: Pigments of photosynthetic biomembranes. Methods Enzymol., 148: 350-382. DOI: 10.1016/00766879(87)48036-1

Mittler, R., 2002. Oxidative stress, antioxidants and stress tolerance. Trends Plant Sci., 7: 405-410. DOI: 10.1016/S1360-1385(02)02312-9

Moharekar, S.T., S.D. Lokhande, T. Hara, R. Tanaka and P.D. Chavan, 2003. Effect of salicylic acid on chlorophyll and carotenoid contents of wheat and moong seedlings. Photosynthetica, 41: 315-317. DOI: 10.1023/B:PHOT.0000011970.62172.15

Morant-Manceau, A., E. Pradier and G. Tremblin, 2004. Osmotic adjustment, gas exchanges and chlorophyll fluorescence of a hexaploid triticale and its parental species under salt stress. J. Plant Physiol., 161: 25-33. DOI: 10.1078/0176-1617-00963

Oertil, J.J., 1996. Effect of external salt concentration on water relations in plants. Soil Sci., 102: 258-263.

Ohki, K., 1978. Zinc concentration in soybean as related to growth, photosynthesis and carbonic anhydrase activity. Crop Sci., 18: 79-82. DOI: 10.2135/cropsci1978.0011183X001800010021x

Singh, B. and K. Usha, 2003. Salicylic acid induced physiological and biochemical changes in wheat seedlings under water stress. Plant Growth Regul., 39: 137-141. DOI: 10.1023/A:1022556103536

Smirnoff, N., 1993. The role of active oxygen in the response of plants to water deficit and desiccation. New Phytol., 125: 27-58. DOI: 10.1111/j.14698137.1993.tb03863.x

Sudhakar, C., A. Lakshmi and S. Giridarakumar, 2001. Changes in the antioxidant enzyme efficacy in two high yielding genotypes of mulberry (Morusalba L.) under $\mathrm{NaCl}$ salinity. Plant Sci., 161: 613-619. DOI: 10.1016/S0168-9452(01)00450-2

Sudhir, P. and S.D.S. Murthy, 2004. Effects of salt stress on basic processes of photosynthesis. Photosynthetica, 42: 481-486. DOI: 10.1007/S11099-005-0001-6

Tiwari, A., P. Kumar, S. Singh and S.A. Ansari, 2005. Carbonic anhydrase in relation to higher plants. Photosynthetica, 43: 1-9. DOI: 10.1007/s11099-0051011-0

Wang, W.X., B. Vinocur and A. Altaman, 2003. Plant responses to drought, salinity and extreme temperatures: Towards genetic engineering for stress tolerance. Planta, 218: 1-14. DOI: 10.1007/s00425003-1105-5

Zhu, J.K., 2002. Salt and drought stress signal transduction in plants. Ann. Rev. Plant Biol., 53: 247-273. 10.1146/annurev.arplant.53.091401.143329

DOI: 